\title{
Konflik Psikologis Tokoh Utama dalam Novel Arini Masih Ada Kereta yang Akan Lewat Karya Mira W
}

\author{
Nurhasanah $^{* 1}$, Darwin Effendi ${ }^{2}$, Puspa Indah Utami ${ }^{3}$ \\ Program Studi Pendidikan Bahasa Indonesia, Universitas PGRI Palembang ${ }^{1,2,3}$ \\ Corresponding email: sanah9806@gmail.com
}

\begin{abstract}
Tujuan penelitian ini adalah untuk mendeskripsikan konflik psikologis yang terdapat di dalam novel Arini Masih Ada Kereta yang Lewat karya Mira W. Metode penelitian yang digunakan adalah metode deskriptif. Sumber data dalam penelitian adalah novel Arini Masih Ada Kereta yang Lewat karya Mira W terdiri dari 232 halaman, tebal buku $20 \mathrm{~cm}$, terbit pada tahun 2018 yang diterbitkan oleh PT Gramedia Pustaka Utama. Teknik pengumpulan menggunakan teknik studi pustaka, teknik baca, dan teknik catat. Sedangkan teknik analisis data menggunakan teknik analisis isi. Berdasarkan hasil penelitian menunjukkan bahwa konflik psikologis yang dibangun dalam novel Arini Masih Ada Kereta yang Lewat karya Mira W dalam bentuk konflik internal dan konflik eksternal. Konflik internal yaitu tokoh utama Arini merasakan perasaan berkecamuk sesaat setelah rasa bahagia tadi ketika melihat bayi yang telah ia lahirkan tersebut. Kemudian, konflik eksternal yaitu tokoh Arini tahu sebuah kenyataan yang dikatakan Helmi seperti tamparan bagi Arini anak yang dianggapnya telah meninggal ternyata masih hidup dan Helmi lah yang merawatnya.
\end{abstract}

Keywords: konflik psikologis, konflik internal, konflik eksternal, tokoh utama, novel

\begin{abstract}
Abstrak
The purpose of this study was to describe the psychological conflicts contained in the novel Arini Masih Ada Kereta yang Lewat by Mira W. The research method used is descriptive method. The data source in the study was the novel Arini Masih Ada Kereta yang Lewat by Mira W. consisting of 232 pages, a book thickness of $20 \mathrm{~cm}$, published in 2018 by PT Gramedia Pustaka Utama. The collection technique uses literature study techniques, reading techniques, and note taking techniques. While the data analysis technique used content analysis techniques. Based on the research results, it shows that the psychological conflicts built in the novel Arini Masih Ada Kereta yang Lewat by Mira $\mathrm{W}$ are in the form of internal conflict and external conflict. Internal conflict, namely the main character Arini felt a raging feeling shortly after the feeling of happiness when she saw the baby she had given birth to. Then, the external conflict, namely the character Arini knows a reality that Helmi said, such as a slap for Arini, a child who he thought had died was still alive and Helmi who took care of him.
\end{abstract}

Kata kunci: psychological conflict, internal conflict, external conflict, main character, novel 


\section{PENDAHULUAN}

Karya sastra dapat dikatakan dunia imajinasi yang diciptakan oleh pengarang (Sayuti, 2000). Imajinasi yang tercipta tersebut berasal dari diri sendiri serta pengaruh dari lingkungan sekitar pengarang (Pujiharto, 2012). Hal tersebut yang menjadi pengaruh bagi cerita yang akan dituliskan. Pengaruh terbesar dari kondisi psikologis pengarang terdapat pada tokoh cerita (Prawira, 2017). Beberapa orang sering beranggapan bahwa tokoh utama merupakan tokoh yang sama dengan pengarangnya, apalagi kalau tokoh tersebut memiliki jenis kelamin yang sama tentu pembaca pasti menerka-nerka bahwa cerita tersebut adalah pengalaman yang nyata dialami oleh pengarang.

Ada banyak pengarang yang menghasilkan karya sastra yang berbeda-beda. Salah satu dari karya sastra tersebut yaitu novel. Novel merupakan buah pikiran pengarang yang sengaja direka untuk menyatakan buah pikiran atau ide, diolah penulis yang dihubungkan dengan kejadian atau peristiwa di sekelilingnya, bisa juga merupakan pengalaman orang lain maupun pengalaman penulis, pola penulisan mengalir secara bebas yang tidak terikat oleh kaidah seperti yang terdapat pada puisi (Yanti, 2015; Nurgiyantoro, 2018). Novel merupakan karya sastra yang banyak sekali penggemarnya, banyak orang yang suka membaca novel karena dengan membaca novel seseorang dapat belajar tentang nilai-nilai di dalamnya (Effendi \& Hetilaniar, 2019; Sulaeman dkk., 2020).

Psikologi sastra menjadi ilmu yang mewakili sastra dalam mengungkapkan perasaan dan keadaan jiwa pengarang, karya, dan pembaca sebagai sebab dan akibat terciptanya suatu cerita (Salam \& Fadhillah, 2019; Umam, 2020). Novel sebagai salah satu jenis karya sastra cenderung mengungkap aspek psikologis yang sangat erat hubungannya dengan masyarakat (Minderop, 2010).

Tokoh utama banyak mengalami berbagai konflik yang direka oleh pengarang. Konflik tersebut dibuat oleh pengarang untuk menciptakan kekhasan tersendiri dalam karya sastra yang mereka buat (Noermanzah, 2017). Beda judul, maka berbeda pula konflik yang dibuat oleh pengarang. Semakin menarik konflik yang dibuat oleh pengarang, maka semakin penasaran pula pembaca untuk membaca novel tersebut (Nurhadi \& Awadayani, 2015). Selain untuk menciptakan suatu kekhasan dalam karya mereka konflik juga dibuat untuk memberikan suasana yang naik turun bagi pembacanya (Agustina, 2017). Artinya dengan adanya konflik di dalam cerita, maka pembaca tidak akan mengalami kejenuhan pada saat membaca novel. Konflik yang naik turun tersebutlah yang dapat menimbulkan konflik psikologis pada tokoh utama yang terdapat dalam cerita, karena cerita yang dibuat tidak datar, jadi menyebabkan banyaknya masalah yang akan dialami oleh tokoh utamanya (Etiwati dkk., 2020). Salah satu novel yang memiliki unsur konflik psikologis tokoh utama adalah novel Arini Masih Ada Kereta yang Akan Lewat karya Mira W.

Alasan peneliti memilih novel Arini Masih Ada Kereta yang Akan Lewat karya Mira W karena sangat relevan bila dikaji mengunakan psikologi sastra karena memang tokoh utama yang disuguhkan Mira W ini banyak sekali mengalami gejolak perasaan dengan dibumbui alur yang maju mundur atau campuran sehingga menambah kesan menggugah perasaan ketika membaca novel ini. Mira W menyajikan novel ini dengan bahasa yang mudah dimengerti oleh pembacanya, cerita yang ditawarkan dalam novel ini begitu kompleks sehingga membuat pembaca kagum dengan isi yang ada dalam novel ini.

Masalah yang dikemukakan dalam penelitian ini ada dua yaitu Bagaimanakah konflik internal dan eksternal yang dialami oleh tokoh utama dalam novel Arini Masih 
Ada Kereta yang Akan Lewat karya Mira W? Dan Bagaimanakah usaha-usaha tokoh utama dalam menyelesaikan konflik psikologis dalam novel Arini Masih Ada Kereta Yang Akan Lewat karya Mira W? Tujuan dari penelitian ini adalah untuk mendeskripsikan konflik psikologis tokoh utama dalam novel Arini Masih Ada Kereta yang Akan Lewat karya Mira W. Manfaat dalam penelitian ini dibagi menjadi tiga yaitu, a) bagi pengajaran bahasa dan sastra Indonesia hasil penelitian ini diharapkan dapat menjadi bahan pembelajaran sastra Indonesia untuk mengkaji sebuah karya sastra novel, b) bagi pembaca, penelitian ini diharapkan dapat dijadikan sebagai bahan bacaan sastra Indonesia dalam hal mengkaji novel, c) bagi peneliti lainnya, penelitian ini diharapkan dapat berguna sebagai bahan referensi untuk penelitian tentang konflik psikologis tokoh utama dalam novel Arini Masih Ada Kereta yang Akan Lewat karya Mira W.

Novel karya Mira W yang baru diteliti yaitu novel Di Sini Cinta Pertama Kali Bersemi. Novel ini diteliti oleh Listyarini (2015) tentang Ketegaran Tokoh Melia dalam Novel Di Sini Cinta Pertama Kali Bersemi Karya Mira W. dalam Dunia Pendidikan. Untuk itu, dapat dikatakan bahwa konflik psikologis dalam novel Arini Masih Ada Kereta yang Akan Lewat karya Mira W. belum ada yang meneliti.

\section{METODE}

Dalam penelitian ini peneliti menggunakan metode deskriptif. Metode deskriptif dapat diartikan sebagai prosedur pemecahan masalah yang diselidiki dengan menggambarkan atau melukiskan keadaan subjek atau objek penelitian (novel, cerpen, drama, puisi) pada saat sekarang berdasarkan fakta-fakta yang tampak atau sebagaimana adanya. Sumber data yang digunakan peneliti dalam penelitian ini adalah novel Arini Masih Ada Kereta yang Akan Lewat karya Mira W. Novel ini diterbitkan oleh PT Gramedia Pustaka Utama terbit pada tahun 2018, berjumlah 232 halaman serta tebal buku 20.

Teknik pengumpulan data yang digunakan dalam penelitian ini yaitu menggunakan teknik studi pustaka, teknik baca, dan teknik catat. Studi pustaka dalam penelitian ini yaitu mengumpulkan buku-buku serta jurnal yang berhubungan dengan konflik psikologis tokoh utama, lalu teknik baca yang bersumber dari penelitian ini ialah novel maka penulis membaca terlebih dahulu novel Arini Masih Ada Kereta Yang Akan Lewat karya Mira W. Kemudian teknik catat, penulis mencatat temuan-temuan penting terkait dengan konflik psikologis yang terdapat pada tokoh utama dalam novel Arini Masih Ada Kereta yang Akan Lewat Mira W seperti konflik internal yang terjadi dengan dirinya sendiri dan konflik eksternal yang terjadi antara seseorang dengan sesuatu yang di luar dirinya seperti lingkungan manusia.

Teknik analisis data yang digunakan dalam penelitian ini menggunakan teknik analisis analisis isi. Analisis isi adalah penafsiran, apabila penafsiran dalam metode kualitatif memberikan perhatian pada situasi alamiah maka dasar penafsiran dalam analisis isi memberikan perhatian pada isi pesan. Berikut merupakan langkahlangkah yang dilakukan penliti dalam analisis data :

1) Membaca novel Arini Masih Ada Kereta yang Akan Lewat karya Mira W.

2) Membuat sinopsis novel Arini Masih Ada Kereta yang Akan Lewat karya Mira W.

3) Menganalisis konflik Internal tokoh utama dalam novel Arini Masih Ada Kereta yang Akan Lewat karya Mira W. 
4) Menganalisis konflik Eksternal tokoh utama dalam novel Arini Masih Ada Kereta Yang Akan Lewat karya Mira W.

\section{HASIL}

\section{Konflik Internal}

Konflik internal adalah sebuah konflik yang terjadi pada diri tokoh utama sendiri dan pada diri tokoh lainnya. Cerita kehidupan yang diangkat oleh pengarang dalam novel ini mengenai perjalanan hidup seorang perempuan yang di khianati oleh suami dan sahabatnya sendiri. Berikut beberapa konflik internal tokoh utama dalam novel Arini Masih Ada Kereta Yang Akan Lewat karya Mira W.

"Tetapi sejak kepercayaannya kepada seorang sahabat dikhianati,

Arini memang tidak pernah benar-benar memiliki seorang teman."

(Mira, 2018:30)

Berdasarkan kutipan di atas, novel ini menjelaskan tentang bagaimana konflik internal yang dialami oleh tokoh utama Arini. Rasa percaya kepada sahabat membuat Arini pernah merasakan pahitnya kehidupan. Pengkhianatan yang begitu pedih membuatnya lupa bagaimana rasa memiliki seorang sahabat. Hal tersebut terdapat pada kalimat "tidak pernah benar-benar memiliki seorang sahabat" Ira bukan sekedar sahabat melainkan orang yang sangat dipercaya dalam hidupnya, kejahatan Ira lah yang membuat Arini tidak ingin mengenalnya lagi.

"Arini tidak berani menanyakannya meskipun sebenarnya dia

berhak. Dia diam saja. Membisu dalam kekecewaan."

(Mira, 2018:83)

Berdasarkan kutipan di atas novel ini menjelaskan tentang bagaimana konflik internal yang dialami oleh tokoh utama Arini. Meskipun sekarang Helmi telah resmi menjadi suaminya tetapi Arini tidak pernah mendapatkan haknya sebagai istri bahkan Helmi sedikit pun tidak mau menyentuhnya, Arini hanya menyimpan rasa kecewa dengan diam dan membisu. Hal tersebut terdapat pada kalimat "Membisu dalam kekecewaan".

\section{Konflik Eksternal}

Konflik eksternal adalah sebuah konflik yang terjadi pada diri tokoh utama dan tokoh-tokoh lainnya. Cerita kehidupan yang diangkat oleh pengarang dalam novel ini mengenai perjalanan hidup seorang perempuan yang di khianati oleh suami dan sahabatnya sendiri. Berikut beberapa konflik eksternal tokoh utama dalam novel Arini Masih Ada Kereta Yang Akan Lewat karya Mira W.

"Aku tidak mau ketemu lagi." Ucap Arini

"Kamu betul-betul tidak tertarik pada Helmi?"

"Punya hak apa aku sampai berani tertarik pada cowok sekeren dia?"

(Mira, 2018:16)

Berdasarkan kutipan di atas novel ini menjelaskan tentang bagaimana konflik eksternal yang dialami oleh tokoh Arini dan Ira. Ketika Ira menanyakan perihal untuk bertemu lagi di situlah hati Arini merasakan keraguan sebab Helmi adalah pemuda yang sangat tampan dan tidak hanya satu wanita yang menyukainya. Hal tersebut terdapat pada kalimat "cowok sekeren dia" tidak mungkin Helmi memilih dirinya yang sangat culun dan tidak seperti wanita di luaran sana.

"Arini tidak dapat menutupi perasaan bangganya kalau berjalan di

samping Helmi." (Mira, 2018:63)

Berdasarkan kutipan di atas novel ini menjelaskan tentang konflik eksternal yang dialami oleh tokoh Arini dan Helmi. Perasaan bahagia Arini tidak dapat di 
sembunyikan saat berada di samping Helmi. Hal tersebut terdapat pada kalimat "perasaan bangganya" perlahan Arini mulai menyimpan rasa kepadanya, Arini pun kerap di perlakuan dengan sangat baik oleh Helmi.

\section{Penyelesaian Konflik}

Penyelesaian konflik dalam novel Arini Masih Ada Kereta yang Akan Lewat Karya Mira W adalah ketika Arini mengetahui ternyata anak yang selama ini ia anggap meninggal ternyata masih hidup dan mengidap penyakit ginjal selama 12 tahun. Di sini mulai terjadi penyelesaian konflik antara tokoh utama Arini dengan tokoh-tokoh lainnya.

"Terima kasih karena telah merawat Ella, Ira". Kata Arini sabar.

Suaranya terdengar amat tulus. Tak ada lagi dendam mewarnainya. Ira sendiri heran. Rupanya bukan hanya ginjalnya saja yang diambil. Racun di hatinya juga. (Mira, 2018:220)

Berdasarkan kutipan di atas novel ini menjelaskan tentang bagaimana penyelesaian konflik antara Arini dan Ira. Semua Kenyataan yang terjadi benar-benar mengembalikan sosok Arini seperti dulu, dengan nada amat lembut Arini mengucapkan rasa terima kasih pada sahabatnya. Hal tersebut terdapat pada kalimat "Terima kasih karena telah merawat Ella" seketika semua rasa dendam Arini sirna melihat pengorbanan Ira yang begitu besar pada anaknya. Ira masih tidak percaya melihat semua perubahan pada diri Arini karena yang Ira tau Arini amat sangat membenci dirinya dan Ira merasa semua yang terjadi di hadapannya seperti mimpi.

\section{PEMBAHASAN}

Berdasarkan hasil penelitian yang dilakukan, konflik psikologis tokoh utama yang terkandung dalam novel Arini Masih Ada Kereta Yang Akan Lewat karya Mira W, dapat diketahui bahwa konflik psikologis dalam novel ini terdiri dari konflik internal dan konflik eksternal. Konflik psikolgis adalah permasalahan yang dialami oleh individu yang terjadi karena adanya dorongan psikologis dari individu tersebut yang dilatarbelakangi oleh keadaan individu tersebut sehingga tercipta sebuah konflik yang ada pada jiwa individu tersebut (Alamsyah \& Kosasih, 2020).

Pada sebuah karya sastra konflik psikolgis dapat dialami oleh seorang tokoh yang ditulis oleh pengarang dengan jalan ceritanya tersendiri sehingga menciptakan konflik psikologis pada tokoh rekaan tersebut. Konflik psikologis dalam konflik psikologis tokoh utama yang terkandung dalam novel Arini Masih Ada Kereta Yang Akan Lewat karya Mira W ini peneliti menemukan dua konflik yaitu konflik internal dan konflik eksternal yang dialami oleh tokoh dalam novel Arini Masih Ada Kereta Yang Akan Lewat karya Mira W.

Konflik internal merupakan konflik yang terjadi pada tokoh utama itu sendiri (Aimifrina, 2017). Dalam novel Arini Masih Ada Kereta Yang Akan Lewat karya Mira W ini konflik internalnya ditujukan pada tokoh utama Arini ketika tokoh utama Arini yang memiliki rasa amat percaya kepada sahabatnya sendiri hal itulah yang membuat Arini pernah merasakan pahitnya kehidupan. Pengkhianatan yang begitu sakit yang dilakukan oleh Ira, yang bukan sekedar sahabat melainkan orang yang sangat dipercaya dalam hidupnya, kejahatan yang dilakukan oleh Ira lah yang membuat Arini tidak ingin mengenalnya lagi.

Kemudian konflik internal dalam novel Arini Masih Ada Kereta yang Akan Lewat karya Mira W yaitu saat tokoh utama Arini mengalami perlakuan tidak baik sebagai 
seorang istri. Peristiwa ini terjadi ketika Helmi telah resmi menjadi suaminya tetapi Arini tidak pernah mendapatkan haknya sebagai istri bahkan Helmi sedikit pun tidak mau menyentuhnya. Arini hanya menyimpan rasa rasa kecewa dengan diam dan membisu. Hal tersebut dapat Arini pendam dengan seribu tanya dihatinya, mengapa suaminya tidak mau bermesraan layaknya suami istri pada umumnya.

Konflik eksternal merupakan konflik psikololis yang terjadi dari luar tokoh itu sendiri yang dibantu dengan tokoh lainnya (Najla, 2018). Konflik eksternal yang terdapat pada novel Arini Masih Ada Kereta Yang Akan Lewat karya Mira W yaitu konflik yang dialami antara Arini dan Ira. Ira mendesak Arini untuk bertemu lagi dengan Helmi, hal tersebutlah yang membuat Arini menjadi ragu dan merasa tidak percaya diri untuk bertemu lagi dengan Helmi, karena Arini merasa ia tidak pantas dengan Helmi yang berperawakan tampan. Ketika itu Ira menanyakan perihal untuk bertemu lagi di situlah hati Arini merasakan keraguan sebab Helmi adalah pemuda yang sangat tampan dan tidak hanya satu wanita yang menyukainya. Helmi tidak mungkin memilih dirinya yang sangat culun dan tidak seperti wanita di luaran sana.

Konflik eksternal dalam novel Arini Masih Ada Kereta yang Akan Lewat karya Mira W ketika tokoh Arini dan Helmi menikah. Pada saat itu, Arini merasakan Perasaan yang amat bahagia, Arini tidak dapat menyembunyikan perasaat tersebut saat berada di samping Helmi. Perlahan Arini mulai menyimpan rasa kepadanya, Arini pun kerap diperlakukan dengan sangat baik oleh Helmi.

Setelah konflik intenal dan ekstranal yang terjadi, kemudian peneliti menemukan penyelesaian konflik yang terdapat dalam novel Arini Masih Ada Kereta yang Akan Lewat karya Mira W yaitu, saat Arini tau bahwa anak dari buah cintanya dengan Helmi dulu ternyata masih hidup. Kemudian, diasuh oleh mantan suaminya dan sahabatnya sendiri. Setelah peristiwa penghianatan tersebut Arini sangat membenci Helmi dan Ira, mereka berdua memutuskan untuk menikah dikarenakan semua kedok perselingkuhannya ketahuan. Akhirnya ketika Arini selesai melahirkan Ibu Arini mengatakan bahwa anaknya sudah meninggal semua itu terpaksa ibunya katakan demi kesembuhan mental Arini. Setelah sekian tahun ternyata anaknya Arini dan Helmi mengalami sakit yang parah, sehingga Helmi sudah banyak kehilangan harta dan uang demi mengobati anaknya tersebut. Lalu saat semuanya sudah habis dan tidak bersisa Helmi nekat untuk menemui Arini yang sekarang sudah menjadi wanita yang sukses. Helmi berencana untuk memberitahu Arini bahwa anaknya tersebut sedang sakit dan sangat butuh pertolongan, karena sangat membenci Helmi, Arini sempat tidak percaya kepada Helmi, tetapi Helmi masih meyakinkan Arini dan akhirnya Arini percaya dan tertegun mendengar kenyataan tersebut.

Akhirnya dengan perasaan iba sebagai seorang ibu, Arini merelakan ginjalnya untuk didonorkan dengan anaknya tersebut. Kemudian, Arini juga mengucapkan terima kasih kepada sahabatnya Ira karena telah merawat anaknya tersebut. Akhirnya, Arini dapat berdamai dengan masa lalu dan Arini juga sudah dapat memaafkan Ira dan Helmi.

\section{KESIMPULAN DAN SARAN}

Konflik psikologis dalam novel Arini Masih Ada Kereta yang Akan Lewat karya Mira W bertema pengkhianatan cinta yang dilakukan oleh sahabat dan suaminya sendiri. Konflik psikologis dalam novel Arini Masih Ada Kereta yang Akan Lewat karya Mira W ini yaitu ada konflik internal, konflik eksternal dan terdapat juga penyelesaian konflik. Konflik internal dalam novel Arini Masih Ada Kereta yang Akan Lewat karya Mira W peneliti temukan yaitu sebanyak 13 konflik internal yang dialami 
oleh tokoh utama, 6 konflik internal yang dialami oleh tokoh Ira, dan 5 konflik internal yang dialami oleh tokoh Helmi. Di antara 13 konflik internal tokoh utama yaitu berupa perasaan bahagia, sedih, kecewa, marah dan menangis yang mana semua itu dialami sendiri oleh tokoh utamanya. Kemudian, 6 konflik internal tokoh Ira yaitu berupa perasaan cemburu, kesal, dan bersalah yang mana semua itu dialami oleh tokoh Ira. Selanjutnya, 5 konflik tokoh Helmi yaitu berupa perasaan bersalah, iba, dan perduli yang mana semua itu dialami oleh tokoh Helmi.

Kemudian untuk konflik ekstrenal dalam novel Arini Masih Ada Kereta yang Akan Lewat karya Mira W peneliti temukan sebanyak 19 konflik eksternal yang peneliti temukan pada novel ini. Pada konflik eksternal ini dialami oleh tokoh utama dengan tokoh lainnya sehingga menciptakan konflik dalam jiwa tokoh berbentuk kekeceawaan, kesedihan, kemarahan, dan kebencian. Penyelesaian konflik dalam novel Arini Masih Ada Kereta yang Akan Lewat karya Mira W yang peneliti analisis yaitu saat Arini mengetahui bahwa anaknya masih hidup dan penyelesaiaannya ialah Arini akhirnya bisa memaafkan masa lalunya dan berdamai dengan kedaaan. Kedua, ketika Arini telah mampu untuk membuka hatinya untuk laki-laki lain, setelah bertahun-tahun ia tidak ingin sama sekali untuk mengenal laki-laki, dan pada akhirnya Arini bisa menerima Nick dengan penuh cinta.

Hasil penelitian ini baru sebatas konflik psikologis dalam novel Arini Masih Ada Kereta Yang Akan Lewat karya Mira W dengan menggunakan analisis isi. Untuk itu, bagi peneliti selanjutnya dapat meneliti topik lain atau bisa juga menggunakan teknik analisis yang lain. Bagi guru bahasa Indonesia, hasil penelitian ini bisa dijadikan salah satu contoh dalam memberikan materi menulis novel dengan menggunakan variasi konflik psikologi dalam menulis novel sehingga novel yang ditulis siswa menjadi menarik untuk dibaca dan mengandung nilai kebermanfaatan .

\section{DAFTAR PUSTAKA}

Agustina, R. (2017). Analisis Konflik Tokoh Utama dalam Novel Air Mata Tuhan Karya Aguk Irawan M.N. Paramasastra, 3(1). doi:10.26740/parama.v3i1.1542

Aimifrina, I. (2017). Konflik Internal Tokoh Utama dalam Novel Mengurai Rindu Karya Nang Syamsuddin. Jurnal KATA, 1(1), 32. doi:10.22216/jk.v1i1.1713

Alamsyah, Z., \& Kosasih, D. (2020). Konflik Psikologis Tokoh Utama dalam Novel Budak Teuneung Karya Samsoedi. LOKABASA, 11(1), 102-114. doi:10.17509/jlb.v11i1.25203

Effendi, D., \& Hetilaniar, H. (2019). Pandangan Dunia Pengarang dalam Novel Bulan Terbelah di Langit Amerika Karya Hanum Salsabiela Rais dan Rangga Almahendra serta Implikasinya dalam Pengajaran Sastra. Diksa: Pendidikan Bahasa dan Sastra Indonesia, 5(2), 62-76. doi:10.33369/diksa.v5i2.9707

Etiwati, E., Syukur, L. O., \& Marwati, M. (2020). Konflik dalam Novel Cinta dalam Diam Karya Shineeminka. Jurnal Bastra (Bahasa dan Sastra), 5(3), 289. doi:10.36709/jb.v5i3.13216 
Listyarini, I. (2015). Ketegaran Tokoh Melia dalam Novel di Sini Cinta Pertama Kali Bersemi Karya Mira W. dalam Dunia Pendidikan. Malih Peddas (Majalah IImiah Pendidikan Dasar), 4(2). doi:10.26877/malihpeddas.v4i2.538

Minderop, A. (2010). Psikologi Sastra: Karya Sastra, Metode, Teori, dan Contoh Kasus. Jakarta: Yayasan Pustaka Obor Indonesia.

Najla, F. N. (2018). Potret Perjuangan Tokoh Utama Menghadapi Konflik Kehidupan dalam Novel Sirkus Pohon Karya Andrea Hirata. Asas: Jurnal Sastra, 7(2). doi:10.24114/ajs.v7i2.10020

Noermanzah, N. (2017). Plot in a Collection of Short Stories "Sakinah Bersamamu" Works of Asma Nadia with Feminimism Analysis. Humanus, 16(1), 30. doi:10.24036/jh.v16i1.7015

Nurgiyantoro, B. (2018). Teori Pengkajian Fiksi. Yogyakarta: Gadjah Mada University Press.

Nurhadi, \& Awadayani, D. (2015). Konflik antar Kromadangsa dalam Novel Menikung Karya Umar Kayam dan Novel Pasar Karya Kuntowijoyo. LITERA, 5(1). doi:10.21831/ltr.v5i1.6806

Prawira, P. A. (2017). Psikologi Umum dengan Perspektif Baru. Yogyakarta: Ar-Ruzz Media.

Pujiharto. (2012). Pengantar Teori Fiksi. Yogyakarta: Penerbit Ombak.

Salam, D., \& Fadhillah, D. (2019). Aspek psikologi pada Novel berjudul Assalamualaikum Beijing karya Asma Nadia (Tinjauan Psikologi Sastra). Lingua Rima: Jurnal Pendidikan Bahasa dan Sastra Indonesia, 6(2), 15. doi:10.31000/lgrm.v6i2.1613

Sayuti, S. A. (2000). Berkenalan dengan Prosa Fiksi. Yogyakarta: Gama Media.

Sulaeman, A., Goziyah, Purawinangun, I.A., Noermanzah. (2020). Social Value in the Novel Hatta: Aku Datang karena Sejarahby Sergius Sutanto as Teaching Materials in Teaching Literature in Schools. International Journal of Scientific and Technology Research, 9(3). 611. http://www.ijstr.org/paperreferences.php?ref=|JSTR-0320-32332

Umam, K. (2020). Delirium Kekuasaan: Kajian Psikologi Sastra pada Lakon Amangkurat-Amangkurat karya Goenawan Mohamad. Nusa: Jurnal IImu Bahasa dan Sastra, 15(1), 134-143. doi:10.14710/nusa.15.1.134-143

Yanti, C. S. (2015). Religiositas Islam dalam Novel Ratu yang Bersujud Karya Amrizal Mochamad Mahdavi. Jurnal Humanika, 3(15), http://ojs.uho.ac.id/index.php/HUMANIKA/article/view/585 